\title{
Initial spacing has little influence on transient epicormic shoots in a 20-year-old sessile oak plantation
}

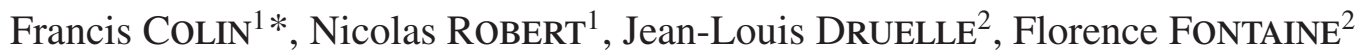 \\ ${ }^{1}$ UMR 1092 INRA-ENGREF, Laboratoire des Ressources Forêt-Bois, INRA-Nancy, 54280 Champenoux, France \\ ${ }^{2}$ UFR Sciences, Moulin de la Housse, Laboratoire de Stress, Défenses et Reproduction des Plantes, Bâtiment 18, BP 1039, \\ 51687 Reims Cedex 2 France
}

(Received 18 July 2007; accepted 31 January 2008)

\begin{abstract}
-
- Epicormics are important defects of oak timber which originate from suppressed buds placed early and develop into epicormic shoots depending on the light available, which in turn depends on stand density. In this context, our objective was to assess the epicormic shoots present in a 20 -year-old experimental plantation of sessile oak and to test and quantify the effect of the three initial densities applied: 1333, 2667 and 5333 stems/ha.

- In the 3 stand densities, epicormic shoots were mostly transient and were rarely clustered. A significant but negligible effect of the density on the epicormic length and on the variables related to epicormic counts appeared: the longest epicormic shoots were present in densities 1333 and 2667 while their means were significantly lower for density 5333. When considering the tree descriptors, the best explanatory models of the different epicormic counts involved their relative variations, especially the relative increment (RIV) in the product V $=$ HEIGHT.DBH ${ }^{2}$. More precisely, emergence of epicormic shoots occurred particularly when trees fell below a threshold value of RIV $=0.26$. Such trees belonged mainly to the two highest densities: 2667 and 5333 stems/ha.

- When considering only epicormics, none of the tested densities can be recommended. Trees which bear the most numerous epicormic shoots will be naturally eliminated by stand competition.
\end{abstract}

epicormic shoots / plantation spacing / Quercus petraea

Résumé - L'espacement à la plantation a peu d'influence sur les gourmands éphémères observés en plantation de chêne sessile âgée de 20 ans. - Les épicormiques sont des défauts importants du bois de chêne. Ils sont issus de bourgeons latents déposés très tôt sur le tronc. Ils peuvent éventuellement se développer en gourmands, selon l'éclairement qui dépend de l'espacement des arbres. Dans ce contexte, nous avons étudié l'effet de la densité de plantation (1333, 2667 et 5333 tiges/ha) sur le développement des pousses épicormiques sur des chênes sessiles âgés de 20 ans.

- Dans les trois densités, les pousses épicormiques ne persistent pas et sont généralement isolées. Un effet significatif mais négligeable sur la longueur des épicormiques a été observé : les pousses les plus longues sont présentes dans les densités 1333 et 2667 alors qu'elles sont plus courtes dans la densité 5333. Vis à vis des caractéristiques dendrométriques de l'arbre, les modèles les plus explicatifs des différentes variables de comptage font intervenir la variation relative RIV du produit V = H.D130 2 entre les deux campagnes. Plus précisément, en dessous d'une valeur seuil de RIV = 0,26, l'apparition des pousses épicormiques est significativement augmentée; les arbres dans cette situation appartiennent majoritairement aux densités les plus fortes 2667 et 5333 tiges/ha.

- En ne prenant en compte que les gourmands, on ne peut recommander une densité particulière. Les arbres qui portent le plus de gourmands sont les moins vigoureux ; ils seront éliminés naturellement par la compétition.

pousses épicormiques / espacement à la plantation / Quercus petraea

\section{INTRODUCTION}

It is widely accepted that epicormics can drastically reduce the market value of oak timber (Schmerberg, 1997; Smith, 1966) and log-grade oak (Meadows and Burkhardt, 2001; Stubb, 1986), which in turn results in a significant loss of potential revenue to the landowner. Lumber grade and lumber value are reduced as well (Courraud, 1987; Meadows and Burkhardt, 2001); because epicormic wood defects such as "catspaws" make wood unsuitable for veneer or high-grade furniture (Joyce et al., 1998) and thick epicormic branches produce knots which influence the quality of sawn goods, as do sequential branches, particularly when they are dead. Epicormics comprise various morphologies: epicormic buds, epicormic shoots which produce actual knots, epicormic clusters of buds and short shoots which produce "catspaws" inside the bole, and short, thick shoots bearing superposed buds and short twigs. In this paper we focus on epicormic shoots. From results obtained on different species (Church and Godman, 1966; Fink, 1980; Fontaine, 1999; Fontaine et al., 2001; Kormanik and Brown, 1969), it is stated that epicormic shoots originate from buds of either primary origin, which means that they were placed during shoot elongation at welldeveloped leaf axils or at scale axils especially at growth unit

* Corresponding author: colin@nancy.inra.fr 
Table I. Main features of the experimental plots.

\begin{tabular}{|c|c|c|c|c|c|c|c|c|c|}
\hline \multirow[t]{2}{*}{$\begin{array}{l}\text { Initial } \\
\text { density }\end{array}$} & \multirow[t]{2}{*}{$\begin{array}{c}\text { Block } \\
\mathrm{n}^{\circ}\end{array}$} & \multirow{2}{*}{$\begin{array}{c}\text { Density } \\
\text { in } 1990 \\
\left(\text { stems/ha) }{ }^{\mathrm{a}}\right.\end{array}$} & \multirow{2}{*}{$\begin{array}{c}\text { Density } \\
\text { in } \\
1994^{\mathrm{a}}\end{array}$} & \multirow{2}{*}{$\begin{array}{c}\text { Density } \\
\text { in } \\
1997^{\mathrm{b}}\end{array}$} & \multirow[t]{2}{*}{$\begin{array}{l}\text { Density } \\
\text { in } 2000^{c}\end{array}$} & \multirow{2}{*}{$\begin{array}{c}\text { Basal } \\
\text { area in } 2000 \\
\left(\mathrm{~m}^{2} / \mathrm{ha}\right)\end{array}$} & \multirow{2}{*}{$\begin{array}{l}\text { Relative density } \\
\text { index* in } \\
2000 \text { (RDI) }\end{array}$} & \multicolumn{2}{|c|}{$\begin{array}{l}\text { Average girth } \\
\text { in } 2000 \text { in } \mathrm{cm}\end{array}$} \\
\hline & & & & & & & & Average & Standard dev. \\
\hline \multirow{3}{*}{1333} & 2 & 1333 & 1226 & 1173 & 1146 & 16.1 & 0.55 & 38.6 & 12.3 \\
\hline & 3 & 1333 & 1280 & 1253 & 1200 & 19.4 & 0.65 & 43.7 & 11.2 \\
\hline & 2 & 2667 & 2560 & 2019 & 1867 & 20.1 & 0.71 & 35.9 & 10.4 \\
\hline \multirow[t]{2}{*}{2667} & 3 & 2667 & 2667 & 2476 & 2115 & 19.9 & 0.72 & 34.0 & 9.9 \\
\hline & 2 & 5333 & 5120 & 4759 & 3795 & 21.6 & 0.84 & 25.6 & 8.4 \\
\hline 5333 & 3 & 5333 & 5226 & 4225 & 3364 & 23.7 & 0.90 & 28.2 & 8.4 \\
\hline
\end{tabular}

* The Relative density index (or Reinecke density index) is calculated according to RDI $=\mathrm{N} . \mathrm{Cg}^{a} / \mathrm{b}$ with $\mathrm{N}$ and Cg being number of stems per ha, dominant girth, respectively, $\mathrm{a}=1.701$ and $\mathrm{b}=\mathrm{e}^{14}$ (Dhôte, 1997).

${ }^{a}$ Up to 1997 , the density per plot was estimated based on the mortality observed in a systematic sample of 50 trees.

${ }^{b}$ In 1997, the density was estimated based on the number of living trees observed in the systematic sample consisting of every other row of trees, this means a maximum of 50, 70 or 130 trees according to the densities 1333, 2667, 5333, respectively.

${ }^{c}$ In 2000, the density and Rdi were calculated from all living trees per plot, on which girth was measured.

limits, or that they were of secondary origin, forming at the base of thick buds or lateral sequential branches.

To trigger bud break, changes in light conditions are not sufficient (Books and Tubbs, 1970; Fabricius, 1932; Wignall and Browning, 1988). Instead, the main factors that affect the propensity of individual hardwood trees to produce epicormic branches are related to stress: climatic stress, prolonged flooding or drought, unfavourable site characteristics such as unsuitable soil texture, excessive wetness or low fertility, stand conditions such as over-stocking or rapid release, stand-level disturbances such as storms, partial felling, attacks by leaf- and bud-eating insects, or incidence of diseases (Evans, 1965; Il'Yushenko and Romanavskij, 2000; Meadows, 1995; Spiecker, 1991). Il'Yushenko and Romanovskij (2000), who synthesised previous Russian results on Quercus robur, consider that the epicormic shoots which develop following changes in growth conditions do not always develop into actual epicormic branches. A large proportion of these shoots die just after their emergence, especially if light is insufficient. From the Quercus mongolica stands they studied, Yokoi and Yamaguchi (1996) suggested that "the epicormic branches emerge constantly in a closed stand" and that "although the light conditions are insufficient for the survival of epicormic branches in a closed stand, the change in light conditions caused by thinning may result in a large survival rate of epicormic branches and their development".

In this context, our objective was to assess the epicormic shoots present in a 20-year-old experimental plantation of sessile oak and to test and quantify the effect of the three initial densities applied: 1333, 2667 and 5333 stems/ha.

\section{MATERIALS AND METHODS}

\subsection{Site and experimental design}

The experimental plantation was established in spring 1981 in the state-owned forest of Lyons-la-Forêt in Normandy, France (49 $28^{\circ}$, latitude, $1^{\circ} 34^{\prime}$ longitude). The soil in the study site was a brown soil, leached to depths varying from 45 to $65 \mathrm{~cm}$. Hydromorphic pseudogleying with iron stains appeared below $45-65 \mathrm{~cm}$. Annual precipitation averaged $833 \mathrm{~mm}$ and annual temperature averaged $10.5^{\circ} \mathrm{C}$, calculated for the period 1992-2000.

The initial objective of the experiment was to analyse and model the influence of initial densities on the growth and morphology of young sessile oaks. Three tree-spacings were tested corresponding to the initial densities: 1333, 2666 and 5333 stems/ha. The highest densities tested corresponded to densities recommended in the past, while the lowest density corresponded to the recently recommended density (for instance, Jarret, 2004). In 1981, ferns were treated with glyphosate herbicide and the plantation was then ploughed. Four blocks were delineated according to soil-depth differences, and each was divided into three plots; the three density level treatments were distributed randomly throughout these plots. In each block, 1-yearold, bare-rooted sessile oak stocks with an average height of $25 \mathrm{~cm}$, of "Forest of Roumare" provenance, were planted in rows $2.5 \mathrm{~m}$ apart and within a row at a distance of $3,1.5$ or $0.75 \mathrm{~m}$, depending on the three increasing densities. In the following years, the plots were kept free of woody vegetation or herbaceous vegetation taller than $0.50 \mathrm{~m}$ by regular mechanical operations.

In the present study, we selected the two blocks (blocks 2 and 3) that were the most similar out of the four blocks initially established, in terms of soil properties and tree growth. Consequently, we did not test the block effect.

Table I shows that at high initial densities, the average girths were lower, the basal areas were slightly higher and the Relative Density Index (RDI) values (Dhôte, 1997) were higher as well, expressing higher pressure of competition than at lower densities. We observed a particularly steep decrease in the number of trees in the period 1997-2000, reflecting a high rate of natural thinning during this period.

\subsection{Measurements}

In 1998, a healthy tree was selected every two trees, to have a balanced representation of the girth distribution in each density. In 2000, we retained the still living trees among the trees selected in 1998. Consequently, 177 trees were sampled during both measurement periods (60 in density 133, 63 in density 2667 and 54 in density 5333). 
Tree vigour was quantified by all the available tree descriptors based on height $(\mathrm{H}$ in $\mathrm{cm}$ ) and girth ( $\mathrm{G}$ in $\mathrm{mm})$, measured in 1997 and 2000 (accuracy 2\%) for each sample tree: the estimated volume $\left(\mathrm{V}=\mathrm{H} . \mathrm{G}^{2}\right.$ in $\left.\mathrm{m}^{3}\right)$, the ratio $\mathrm{H} / \mathrm{DBH}(\mathrm{HoD}$ in $\mathrm{cm} / \mathrm{cm})$ and more simply, the product $\mathrm{H} \times \mathrm{DBH}\left(\mathrm{HD}\right.$ in $\left.\mathrm{m}^{2}\right)$. Absolute and relative increments in height (IH in $\mathrm{cm}$ and $\mathrm{RIH}$ in $\mathrm{cm} / \mathrm{cm}$, respectively), in girth (IG in $\mathrm{mm}$ and RIG in $\mathrm{mm} / \mathrm{mm}$, respectively), in HoD (IHoD and RIHoD in $\mathrm{cm} / \mathrm{cm}$ ), in HD (IHD in $\mathrm{m}^{2}$ and RIHD in $\mathrm{m}^{2} / \mathrm{m}^{2}$ ) and in estimated volume (IV in $\mathrm{m}^{3}$ and RIV in $\mathrm{m}^{3} / \mathrm{m}^{3}$, respectively) were calculated between 1997 and 2000 .

Epicormic shoots were recorded all around the trunk, from the ground to $4 \mathrm{~m}$, in June 1998 (plantation age of 18 years) and in June 2000 (plantation age of 20 years). An individual survey of the epicormic shoots found in 1998 was not performed. Consequently, the epicormic shoots recorded in 2000 might be different from those observed in 1998.

An epicormic shoot was considered to be living when green parts could be recognised. It could have one or more growth units (GUs) bearing green leaves, allowing polycyclism to be quantified: a monocyclic shoot with only $1 \mathrm{GU}$, a bicyclic shoot with $2 \mathrm{GUs}$, etc. A growth unit $(\mathrm{GU})$ is defined as a segment of an axis that appears during a period of continuous elongation (Barthélémy and Caraglio, 2007). An epicormic shoot which bore only one GU, whether dead or living, was considered to be one year old. A living epicormic shoot, bearing one or more GUs with green leaves, which had one previous brown GU without leaves or with dead and brown leaves, was considered to be two years old. If a living epicormic shoot had more than one previous brown growth unit with no leaves or dead and brown leaves, the epicormic shoot was considered to be at least two years old. Two-year-old and at least two-year-old epicormics were grouped into the age class "age two years or more".

We observed that epicormic shoots were either isolated or clustered. An isolated shoot was a unique shoot emerging directly from the trunk, while a cluster of shoots was composed of at least two shoots, which were all counted.

In 1998 and 2000, the number of living epicormic shoots (NLE 98 and $\mathrm{NLE}_{00}$ ) and the total number of epicormic shoots, living or dead ( $\mathrm{NE}_{98}$ and $\mathrm{NE}_{00}$ ), as well as the length of the living epicormics ( $\mathrm{L}_{98}$ and $\mathrm{L}_{00}$ in $\mathrm{cm}$ ) were recorded; VNE and VNLE indicated the variation in NE and NLE between 1998 and 2000. In addition, we calculated the proportion of living epicormic shoots $\left(\mathrm{PLE}_{00}=\mathrm{NLE}_{00} / \mathrm{NE}_{00}\right)$ for the year 2000 and of 1-year-old living epicormic shoots for the year $2000\left(\mathrm{P}_{\mathrm{YEAR}} \mathrm{YE}_{00}=\mathrm{N} 1 \mathrm{YEAR}_{00} / \mathrm{NE}_{00}\right)$. In 2000 only, the number of growth units $(\mathrm{GU})$ and the age $\left(\mathrm{AGE}_{00}\right)$ of the living epicormic shoots were noted when possible. The polycyclism of the epicormic shoots was assessed in the year 2000 only, based on the number of GUs. Epicormic clusters were recorded and the proportion of epicormic shoots in clusters was calculated. All the variables introduced in this paragraph were considered as "epicormic" variables.

For brevity, we decided to show the results obtained for only "epicormic" variables recorded in 2000 and their variations between 1998 and 2000. The tests were also performed in 1998, but since their results were equivalent to the results of 2000, they are not presented.

\subsection{Statistical methodologies}

The general characteristics of epicormic shoots were analysed on the basis of histograms of "epicormic" variables. The density effect on frequencies was tested with the help of non-parametric tests (Kruskal-Wallis, Median, Cramer-von-Mises tests; Sprent, 1989).
The effect of the density on epicormic length was tested using linear models after log-transformation. In the case of variables of proportions we performed Chi-square tests.

The available tree descriptors were screened using generalised linear models, i.e. Poisson and Negative binomial models, depending on the distribution of the dependent variable and variance behaviour (McCullagh and Nelder, 1983; Zelterman, 1999). In a few cases, a log-transformation was applied to recover normality and homoscedasticity and thus a general linear model could be applied. A logistic model was used for proportions (Collett, 1991).

The goodness-of-fit of the models was tested:

- with the model $P$-value (F-test for general linear models, Chisquare test for generalised linear models);

- with $R^{2}$ for general linear models or with ratio deviance/degree of freedom for generalised linear models, as this latter ratio had to be close to " 1 " for a well adjusted model; in this case no equivalent of the coefficient of determination is available; conversely, for logistic models "logistic" $R^{2}\left(R_{L}^{2}\right)$ and max-rescaled $R^{2}\left(M R-R_{L}^{2}\right)$ have been created as part of the deviance explained by the model (for the definition and comments on these coefficients see, for instance, Schalenberg and Pierce, 2002, p. 343);

- by visual inspection of plots with residual or deviance residuals versus predicted values.

Tests of differences between densities were carried out according to the methodology of contrasts either for general linear models, or with generalised linear models only, in the case when the effect tested was present as the main effect. All statistical analyses were performed with SAS release 8.2 (procedures PROC NPAR1WAY, PROC GLM, PROC LOGISTIC and PROC GENMOD; SAS, 1999).

\section{RESULTS}

The values of the different tree descriptors according to the three initial densities of the plantation are provided in Table II. The tree descriptors which have the highest coefficient of variation, $\mathrm{CV}$, and thus the highest range of variability are $\mathrm{V}_{00}$, ( ${ }_{00}$ means in the year 2000), IG, IV, RIG and RIV. According to the results noted in column " $R^{2}$ of density effect" the differences between densities of the tree descriptors were the highest for the variables $\mathrm{HoD}_{00}, \mathrm{G}_{00}, \mathrm{~V}_{00}$ and IV; the differences were the lowest for IH, RIHoD and RIG. In addition, it can be seen that the density effect was not significant for the variables $\mathrm{DH}_{00}$ and $\mathrm{IHoD}$ alone. According to the results of the contrasts performed with analysis of variance (data not shown), the tree descriptors in densities 2667 and 5333 appeared to be very close.

The frequency distributions of all epicormic shoots per tree $\left(\mathrm{NE}_{00}\right)$ (Figs. 1A, 1B and 1C) and of living epicormic shoots per tree (NLE $\left.\mathrm{N}_{00}\right)$ (Figs. 1D, 1E and 1F) showed a large number of trees which bore a few epicormic shoots, while only a few trees bore a lot of them. No statistical differences between the epicormic distributions in the three densities could be found.

In Table III for the year 2000, various characteristics were introduced and calculated for all epicormic shoots pooled by densities or for all densities together. The statistical tests showed:

- for the proportion of living epicormic shoots (PLE $\left.\mathrm{P}_{00}\right)$ no significant difference between densities 2667 and $5333(P=0.22)$, while significant differences appeared between densities 1333 and $2667(P<0.0001)$ and densities 1333 and $5333(P=$ $0.0018)$; 
Table II. Range of variation in the tree descriptors of the year 2000 (Mean and Coefficient of Variation CV\%) and density effect according to "classic" ANOVA with density as the classification factor ( $N S=$ not significant). The last three columns provide average values for each density. Definitions of the variables and units are given in the text.

\begin{tabular}{|c|c|c|c|c|c|c|c|}
\hline Descriptors & & Mean & $\mathrm{CV} \%$ & $\begin{array}{c}R^{2} \text { of density } \\
\text { effect }\end{array}$ & $\begin{array}{c}\text { Density } \\
1333\end{array}$ & $\begin{array}{c}\text { Density } \\
2667\end{array}$ & $\begin{array}{c}\text { Density } \\
5333\end{array}$ \\
\hline \multirow[t]{5}{*}{ Current tree descriptors } & $\mathrm{G}_{00}$ & 360.35 & 32 & 0.25 & 435.8 & 343.6 & 296.1 \\
\hline & $\mathrm{H}_{00}$ & 975.78 & 12 & $N S$ & 970 & 982.6 & 974.3 \\
\hline & $\mathrm{V}_{00}$ & 0.12 & 68 & 0.18 & 0.16 & 0.11 & 0.08 \\
\hline & $\mathrm{HoD}_{00}$ & 92.57 & 28 & 0.35 & 72.4 & 96.7 & 110.2 \\
\hline & $\mathrm{HD}_{00}$ & 3.6 & 40 & 0.15 & 4.31 & 3.46 & 2.98 \\
\hline \multirow[t]{5}{*}{ Variations in tree descriptors } & IG & 43.20 & 71 & 0.16 & 60.0 & 37.3 & 31.4 \\
\hline & $\mathrm{IH}$ & 172.76 & 27 & 0.08 & 184.0 & 178.6 & 153.4 \\
\hline & IV & 0.04 & 79 & 0.18 & 0.06 & 0.04 & 0.03 \\
\hline & IHoD & -10.66 & -55 & $N S$ & -11.38 & -9.54 & -11.15 \\
\hline & IHD & 1 & 52 & 0.17 & 1.28 & 0.95 & 0.75 \\
\hline \multirow[t]{5}{*}{ Relative variations in tree descriptors } & RIG & 0.13 & 62 & 0.10 & 0.16 & 0.11 & 0.11 \\
\hline & RIH & 0.22 & 30 & 0.11 & 0.24 & 0.22 & 0.19 \\
\hline & RIV & 0.56 & 46 & 0.13 & 0.69 & 0.52 & 0.47 \\
\hline & RIHoD & -0.11 & -56 & 0.09 & -0.135 & -0.096 & -0.095 \\
\hline & RIHD & 0.38 & 37 & 0.14 & 0.44 & 0.36 & 0.32 \\
\hline
\end{tabular}

- for the proportion of 1-year-old living epicormic shoots (P1YEAR) significant differences were observed whatever the two densities tested $(P<0.02$ in all cases);

- for the age of the living epicormic shoots no significant difference appeared between densities 1333 and $5333(P$-value $=0.1)$; conversely, significant differences appeared between densities 1333 and 2667, as well as between densities 2667 and 5333 $(P<0.0001$ for both tests);

- for the number of GU on living epicormic shoots, trends similar to those for age were observed.

In addition to the information given in Table III, we observed that among the 1-year-old living epicormics, $97.8 \%$ bore only 1 growth unit, while $2.2 \%$ bore 2 growth units.

The length of the living epicormics in $2000\left(\mathrm{~L}_{00}\right)$ is illustrated in Figure 1G. This length was on average $57.2 \mathrm{~mm}$. Using analysis of variance on $\log \left(\mathrm{L}_{00}\right)$, no significant difference could be observed between densities 1333 and 2667, while significant differences occurred between 1333 and 5333, as well as between 2667 and 5333. In addition, Figure $1 \mathrm{G}$ displays the variation in the length of the living epicormics between both measurement campaigns and relating to the different density levels. A reduction of this length from 1998 to 2000 could not be observed when each density was considered separately.

Lastly, we observed that most epicormic shoots were isolated (91\%), the others being clustered by 2, 3 or, rarely, 4 .

The main result of this investigation is that "epicormic" frequencies and proportions are little affected by the initial density of the plantation. More precisely, Table IV shows that density alone was on the one hand not significant in the models fitted to the "epicormic" variables $\mathrm{NE}_{00}, \mathrm{NLE}_{00}, \mathrm{~N} 1 \mathrm{YEAR}_{00}$ and VNLE, and on the other hand, significant but poorly explanatory for VNE, PLE and P1YEAR.

After a broad screening of the possible variables, we observed that RIV and RIHD were the best dependent variables and after various transformations had been completed (square, log, root-square; inverse, etc.) RIV behaved better than RIHD. Consequently, only the models with RIV are provided in Table IV and Figure 2. The different "epicormic" variables showed a decreasing trend, while the tree descriptors increased (Figs. 2A, 2B and 2C). This decreasing trend is due above all to the fact that the lowest values of the epicormic variables appeared above RIV $=0.26$, leading to a decrease in the prediction curve. In addition, a density effect appeared for PLE $\mathrm{P}_{00}$ and VNE (Figs. 2D and 2E, respectively); this effe ct appeared to be common for densities 2667 and 5333 for variable VNE (Fig. 2E). To take such a common trend into account, a dummy variable, zmod, was applied either to the intercept term or to the slope of the different variables (it means as interaction) or to both: if density $={ }^{\prime} 1333$ ' $\mathrm{zmod}=1$, otherwise zmod $=0$ (Tab. IV). The case of the 'epicormic' variable $\mathrm{NE}_{00}$ was the most original. The density effect introduced alone into the general linear model of log-transformed $\mathrm{NE}_{00}$ was not significant (Tab. IV). The RIV effect included alone was relatively weak (model not shown; $P$-value $=0.0049 ; R^{2}=0.04$ ). When the density effect was introduced, after RIV had been included in the form of the dummy variable, zmod, the density effect appeared significant both on the intercept and as an interaction. This resulted in a model with a better explanatory capacity $\left(R^{2}=0.10\right.$, see Tab. IV) although it was still quite modest.

\section{DISCUSSION}

Epicormic shoots observed in our 20-year-old experimental stand were mostly transient and were rarely clustered: they were on average about $60 \mathrm{~mm}$ in length, mainly one year old and mostly contained only one growth unit. Based on the information provided in Table III it can be stated that $45.7 \%$ of the epicormics emerged in $2000(45.7 \%=88.2 \%$ (of 1 year-old epicormics of the living epicormics) $\times 51.8 \%$ (of living epicormics)). This must be considered as an estimation of the emergence rate relative to all epicormic shoots 
A.

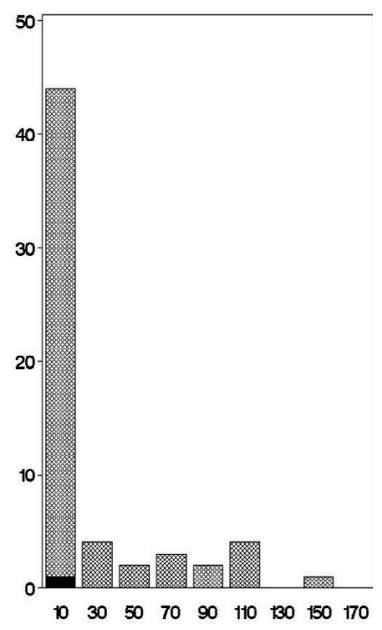

D.

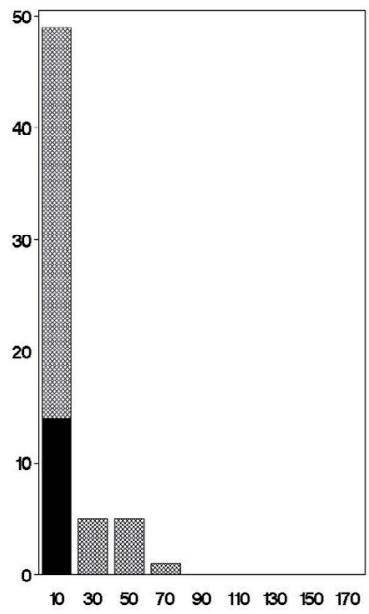

B.

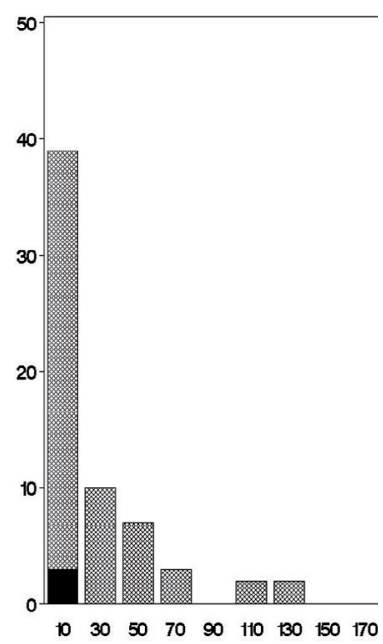

E.

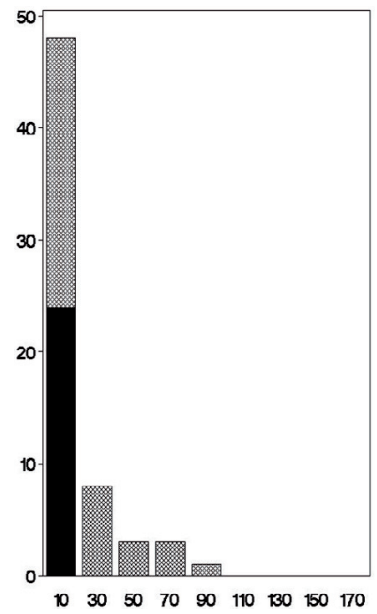

C.

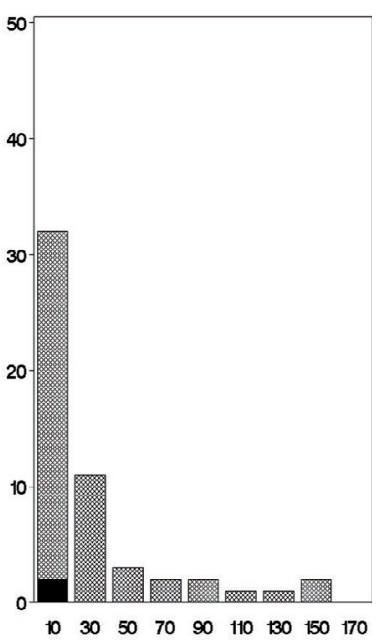

F.

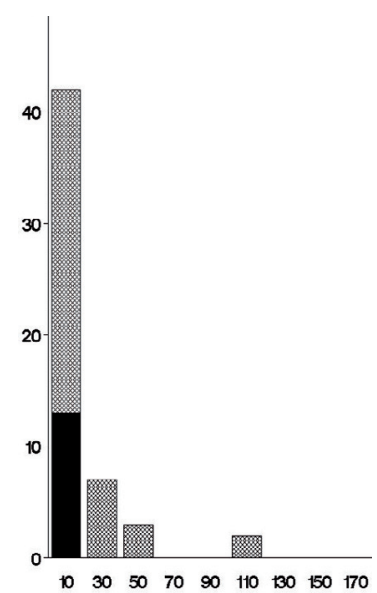

G.

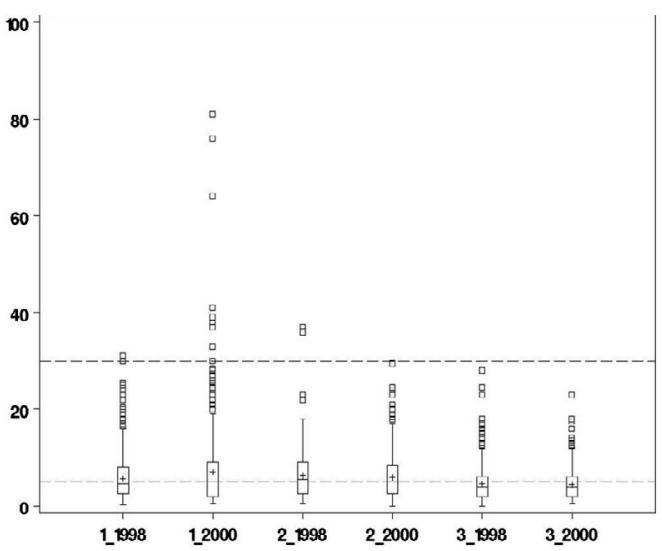

Figure 1. A to F: distributions of epicormic counts according to the initial spacings: number of trees in $\mathrm{Y}$ axis, classes of epicormic frequencies in $\mathrm{X}$ axis. Within the left bar corresponding to the class 0-20, the black portion represents the number of trees bearing 0 epicormic. Histograms $\mathrm{A}, \mathrm{B}$ and $\mathrm{C}$ represent the total number of epicormics $\left(\mathrm{NE}_{00}\right)$ in initial densities respectively 1333, 2667 and 5333 . Histograms $\mathrm{D}$, E and $\mathrm{F}$ represent the number of living epicormic shoots $\left(\mathrm{NLE}_{00}\right)$ in initial densities respectively 1333, 2667 and 5333. G: box-plots of epicormic length according to the densities $(1=1333,2=2667,3=5333)$ and the year $(1998,2000)$. 
Table III. Percentage of living epicormic shoots (PLE) and of 1-year-old living epicormic shoots (P1YEAR), estimated both on the population of all epicormic shoots pooled either by density or for all densities, age and number of Growth Units (GU) on living epicormic shoots.

\begin{tabular}{|c|c|c|c|c|}
\hline & Density 1333 & Density 2667 & Density 5333 & All densities \\
\hline PLE & 56.4 & 48.5 & 50.8 & 51.8 \\
\hline P1YEAR & 35.9 & 46.8 & 40.0 & 40.9 \\
\hline \multicolumn{5}{|c|}{ Age of living epicormic shoots: } \\
\hline 1 year & 86.1 & 94.9 & 82.9 & 88.2 \\
\hline 2 years & 7.9 & 4.5 & 15.1 & 9.1 \\
\hline$>2$ years & 6.0 & 0.6 & 2 & 2.7 \\
\hline \multicolumn{5}{|c|}{ Number of GU on living epicormic shoots: } \\
\hline $1 \mathrm{GU}$ & 83.8 & 93.9 & 84.1 & 87.6 \\
\hline $2 \mathrm{GU}$ & 12.7 & 5.85 & 14.7 & 10.9 \\
\hline$>2 \mathrm{GU}$ & 3.5 & 0.25 & 1.2 & 1.5 \\
\hline
\end{tabular}

present. This agreed well with Yokoi and Yamaguchi's suggestions: "the epicormic branches emerge constantly in a closed stand" (Yokoi and Yamaguchi, 1996).

It is widely accepted that light is the major factor influencing epicormic shoot survival and development (Il'Yushenko and Romanovskij, 2000). If differences in light availability had occurred they would probably have entailed higher light availability in the lower densities, and thus the production of longer epicormic shoots. This was the case at our site: the longest epicormic shoots were present in densities 1333 and 2667 and their means were significantly lower for density 5333. However, the differences were very low. This is not surprising: Wignall and Browning (1988) demonstrated that, before canopy development of a pedunculate oak stand, there was a difference of only $13.5 \%$ in the light measured at $1 \mathrm{~m}$ between two plots; one having been thinned from c. 1600 to c.400 stems/ha and the other having been maintained at c. 1600 stems/ha.

The development of epicormic shoots depends on budbreak, which occurs at the beginning of the leafy period (Harmer, 1990), on light availability in the early spring and then on light availability all through the growing season. We agree with Wignall and Browning (1988) that no light differences occurred at the beginning of the growing season. Therefore, the closure of the canopies was probably nearly equivalent in the three densities, leading to very similar epicormic shoot lengths, life spans and persistence.

One could assume that in 2000 compared with 1998, each plot experienced more intensive competition (Tab. I) and trees received less light on their trunk. Consequently, one could expect that epicormics developed much less, they were shorter and the living epicormics were less numerous, especially in the highest densities. However, Figure $1 \mathrm{G}$ does not confirm this assumption: it cannot be considered that the length decreased whatever the density. This confirms the highly transient characteristic of most epicormic shoots. In addition, light conditions could possibly remain more or less constant due to self-thinning induced by competition (Tab. I).

A density effect was expected on the tree descriptors. This is demonstrated well in Table II. However, these differences did not lead to actual differences in the 'epicormic' counts.

In particular, we observed a lack of relationships between the current dimensions of the trees $(\mathrm{G}, \mathrm{H}, \mathrm{V}, \mathrm{HoD}$ and HD) and the presence (prevalence) of epicormics. This result was not surprising since it had already been observed for other species (Auchmoody, 1972; Hedlund, 1964; Rey-Lescure, 1982). Conversely, the epicormic prevalence was found to be inversely proportional to the $\mathrm{DBH}$ on Larix laricina and Acer saccharum (Rey-Lescure, 1982). In-between the previous extreme situations, Harmer (1992) found very few differences between 10 dominant and 10 suppressed pedunculate oak trees in two 38-year-old stands, the social status dominant/suppressed being quantified by DBH. Concerning accumulative variables other than DBH, Nicolini et al. (2001; 2003) suspected the HoD ratio to be an explanatory tree measurement: trees with high HoD values were likely bearers of epicormic shoots. We did not find an effect of HoD.

In the previous studies, no interpretation of the absence of effect (when observed) of the current tree descriptors has been provided. In our case, we remarked that the epicormic shoots were very ephemeral and that prevalence was very close to incidence. Consequently, we assumed that accumulative tree descriptors were not relevant independent variables to account for the recent changes in tree vigour and thus to predict the counts of the more or less transient epicormic shoots.

A density effect can be revealed when "differential" independent variables such as RIV are tested, leading to a potentially better explanation than "accumulative" tree descriptors. When significant, the density effect originates from the different range of the independent variables depending on the densities, as shown in Table III.

To our knowledge very few former studies have examined the effects of variations or relative variations in tree descriptors as explanatory variables of epicormic prevalence. Only three authors have studied the relationships between epicormic shoot prevalence and radial (cambial) growth: Spiecker (1991) on sessile and pedunculate oaks, Nicolini et al. (2001) on beech and Bachelard (1969 in Nicolini et al., 2001) on Eucalyptus. They observed a general negative relationship between radial growth and epicormic prevalence. This trend was similar to the trend we observed, and in addition we have quantified this trend. More precisely, Spiecker (1991) demonstrated clearly that the mortality of the epicormic shoots was especially high in vigorous trees (with high radial increments) in stands with an understorey, and consequently the number of 
Table IV. Main features of the most explanatory models of the "epicormic" frequencies with RIV and its square-root transformation as independent variables (sqRIV $=\operatorname{sqrt}(\mathrm{RIV})$ ). Density 1: 1333 , density 2: 2667 , density 3: 5333 . Only $P$-values for the effect of the factor and of the retained variables are noted. For logistic models, specific coefficient of determination $\mathrm{R}_{L}^{2}$ and max-rescaled $\mathrm{R}_{L}^{2}\left(\mathrm{MR}-\mathrm{R}_{L}^{2}\right)$ are provided (see text). $N S$ means not significant. ${ }^{*} N=171$ since the proportion with $\mathrm{NE}_{00}=0$ cannot be computed for six trees.

\begin{tabular}{|c|c|c|c|c|c|}
\hline $\begin{array}{l}\text { Dependent } \\
\text { variable }\end{array}$ & Model & Type & Main features & $\begin{array}{c}P \text {-values of the } \\
\text { selected variables }\end{array}$ & $\begin{array}{c}\text { Corresponding } \\
\text { figures }\end{array}$ \\
\hline
\end{tabular}

Total frequencies of epicormics In 2000

$\log \left(\mathrm{NE}_{00}+1\right)=\mathrm{f}($ density $) \quad$ General linear $\quad N=177$

NS

\section{NS}

$\log \left(\mathrm{NE}_{00}+1\right)=\mathrm{f}(\mathrm{RIV}$, density) General linear $\quad N=177$

$\begin{array}{ll}\text { zmod } & P=0.001 \\ \text { RIV.zmod } & P<0.0001\end{array}$

Figure 2A

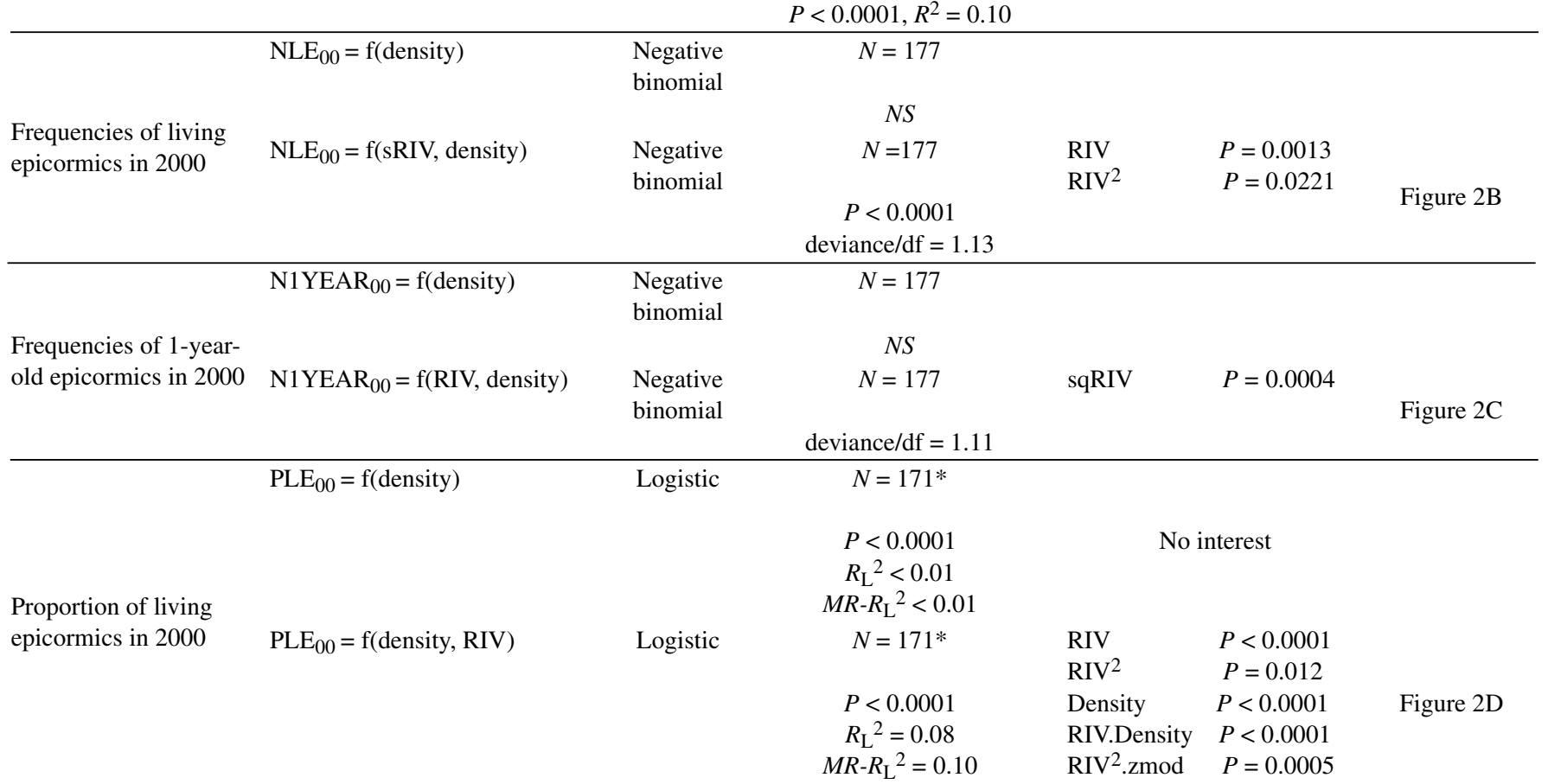

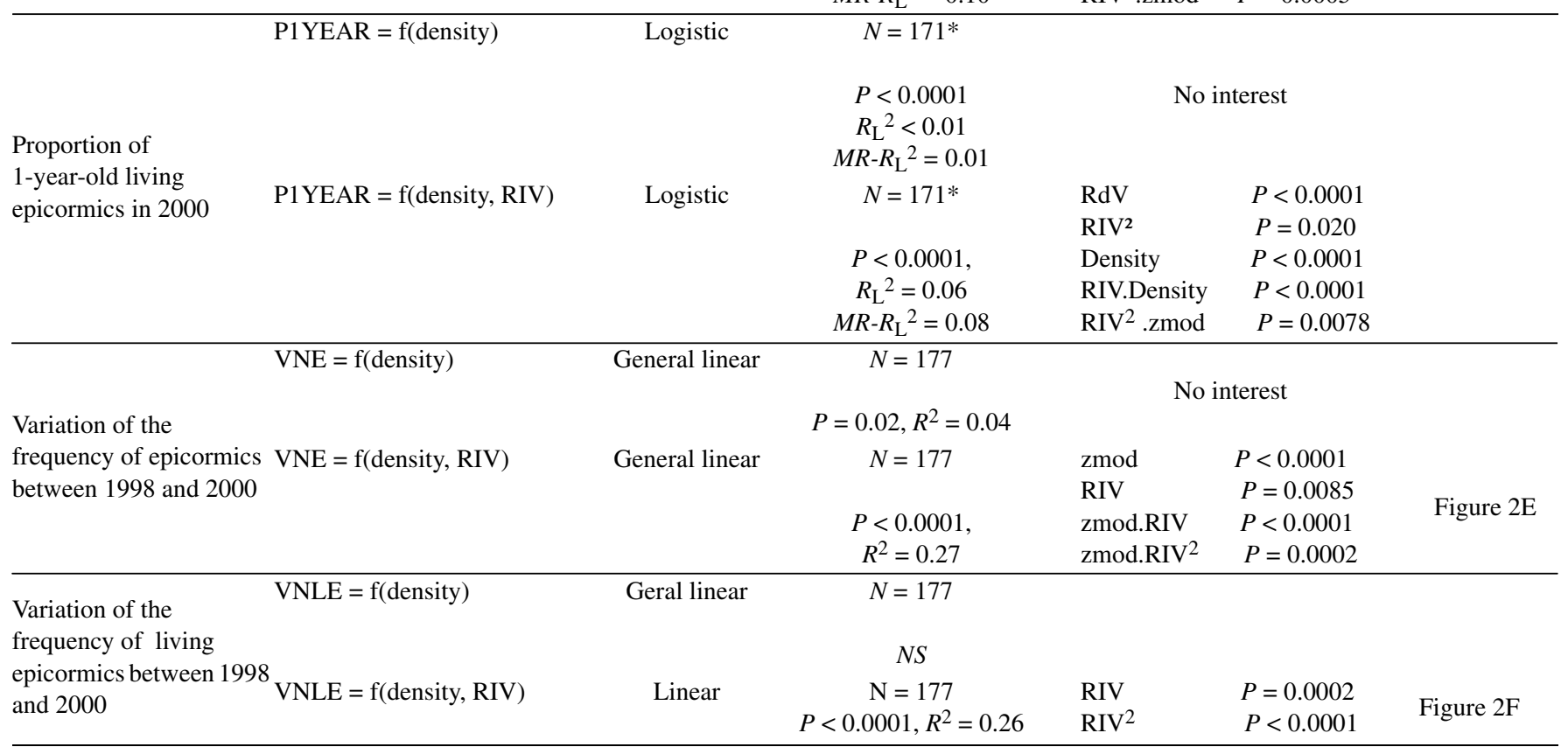


A. Frequency of total epicormics in 2000

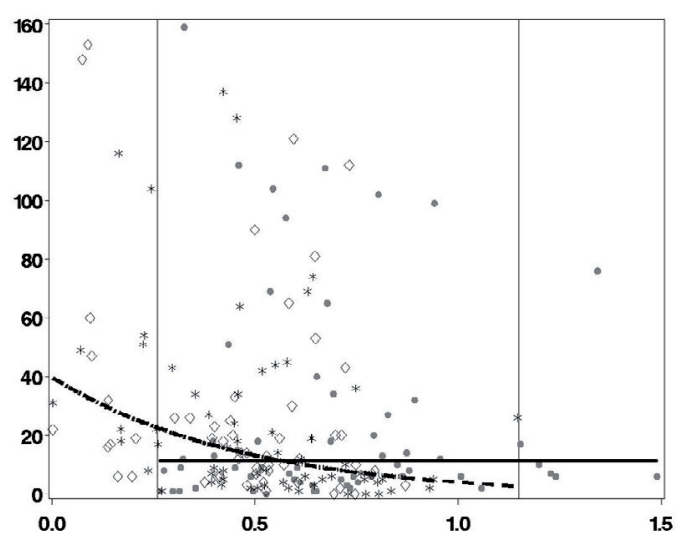

C. Frequency of 1-year-old living epicormics in 2000

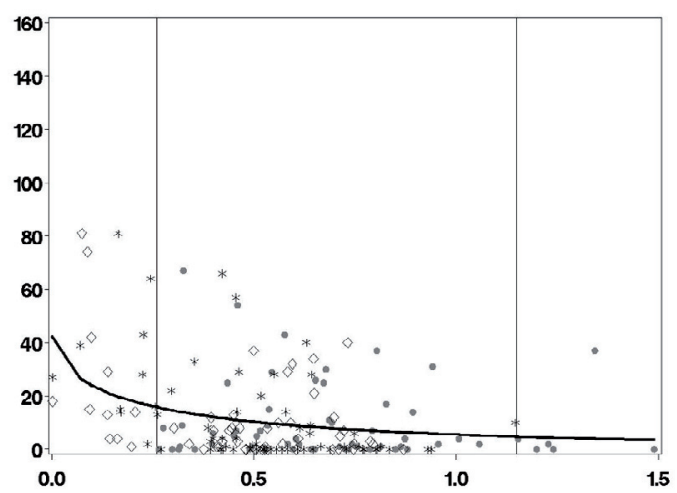

E. Variation of the frequency of epicormics between 1998 and 2000

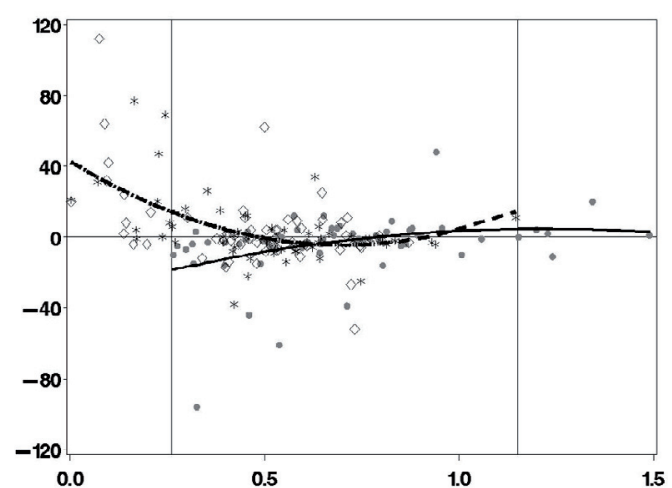

B. Frequency of living epicormics in 2000

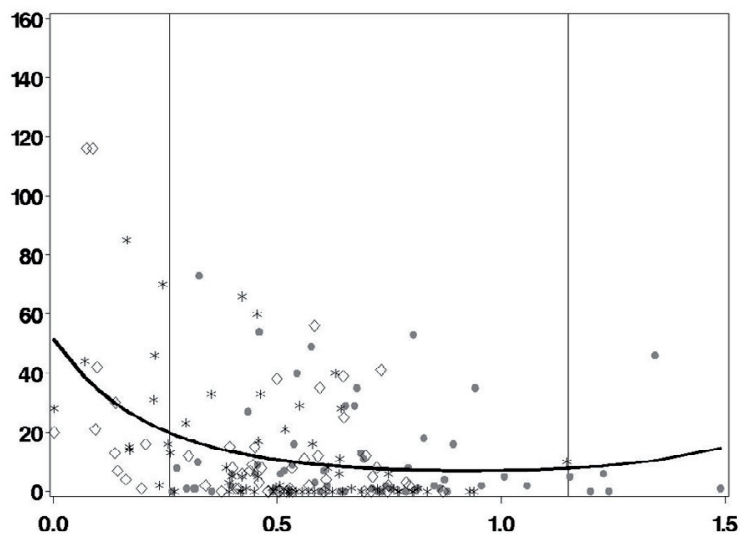

D. Proportion of living epicormics in 2000

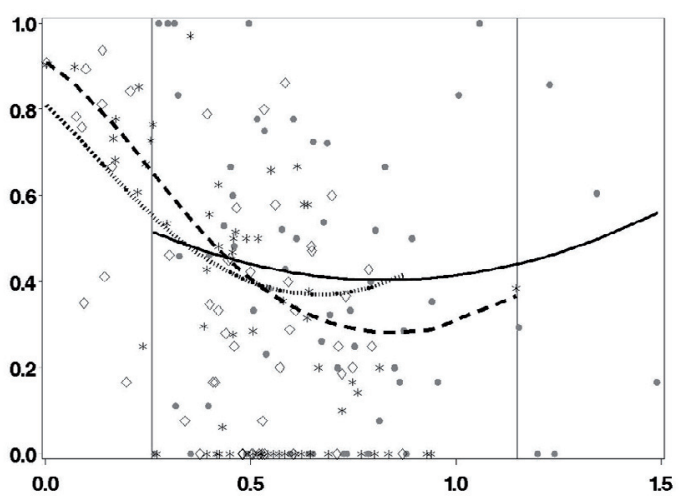

F. Variation of the frequency of living epicormics between 1998 and 2000

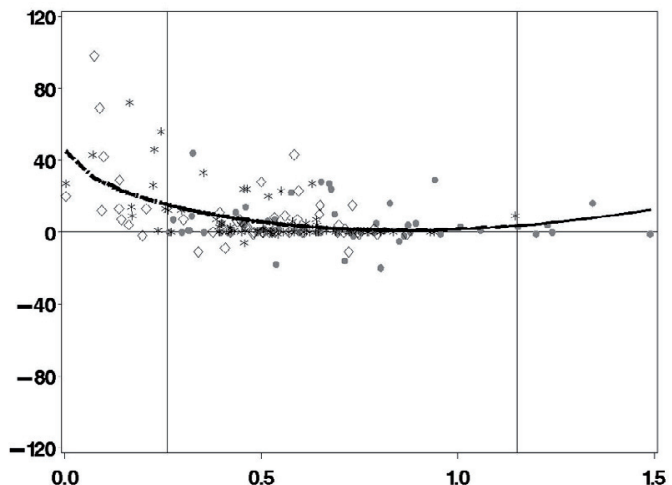

Figure 2. Relationships between RIV (X axis) and "epicormic" variables (Y axis), proportions in D and frequencies in all other graphs. In graph D, the symbols are: density 1333 with dots and continuous line; density 2667 with stars and dashed lines; density 5333 with diamonds and dotted line. In graphs A and E, prediction curves of densities 2667 and 5333 are the same. In the other graphs, prediction curves of all densities are the same. Vertical lines are drawn at $\mathrm{RIV}=0.26$ and $\mathrm{RIV}=1.15$ : below 0.26 no points belong to density 1333 while above 1.15 all points belong to density 1333. In graph $\mathrm{A}$, original $\mathrm{NL}_{00}$ values are displayed after a back-transformation with exp[x]-1. 
living epicormic shoots decreased as radial growth rate increased. We observed the same trend as well.

Epicormic branching is a phenomenon statistically linked with tree vigour and more precisely with a vigour threshold.

Above RIV $=0.26$, low values of the 'epicormic' counts were less numerous (Fig. 2). This observation was fundamental: according to the general understanding of "agony shoots" of German and French foresters (Evans, 1982) and, according to ideas suggested by some scientists (Nicolini et al., 2003), when a tree falls below a given value of growth or relative growth, more epicormic shoots develop from epicormic buds. In addition, trees having fallen below this vigour threshold belonged mainly to densities 2667 and 5333 .

Consequently, we confirm the hypothesis proposed by Bachelard and Nicolini with the renewed wording: when trees are less vigorous, they are likely to bear more epicormics (prevalence) and more new epicormics appear (incidence), particularly when they fall below a given threshold value of vigour. In our case, the vigour indicator was the differential tree descriptor, RIV.

The density effect, which we found to be very weak, as did Schmalz et al. (1997), could depend on the range of densities tested, which was probably not large enough to produce a firm effect, and also on the species. Both aspects could explain why on Hibiscus elatus, Ashton et al. (1991) found such an impressive density effect.

One must admit that the models introduced were poorly explanatory. Among the factors not included in our models, genetics must be mentioned. The genetic origin of the propensity of some trees to develop epicormics, especially after thinning, in spite of having good vigour, has already been assumed (Evans, 1982; Krahl-Urban, 1955; Spellmann, 1995), and more rarely observed on various species (Auchmoody, 1972; Remphrey and Davidson, 1992; Ward, 1992). ;

From our results and from the restricted point of view of current epicormic branching, we cannot recommend one specific initial density for oak plantations. Indeed, whatever the initial density, after 20 years without thinning, the most vigorous trees were, on average, equally prone to developing epicormic shoots. Conversely, we demonstrated clearly that the highest initial densities produced more trees which fell below the threshold indicator of vigour, but these densities still had the highest number of trees (between 2000 and 4800, Tab. I). Consequently, these "less vigorous trees" can be, and are likely to be, eliminated naturally by self-thinning without impairing the overall potential quality of the plots.

This conclusion is not definitive since we will have to consider information on how trees will react after the first thinning, whatever their density, vigour and the frequency of epicormics they bear.

Acknowledgements: This research was partly supported by the ONF, "Office National des Forêts". The authors thank François Ningre for the management of the experimental plots, Catherine Collet for valuable comments on the initial manuscript, Bruno Garnier for technical assistance, Marie-Jeanne Lionet and David Gasparetto from the ENGREF Forestry Library in Nancy for bibliographic support, Roswitha Judor and Jean-Claude Péguet at the
INRA Versailles for translations from Russian and German to French, Aldyth Nys for English corrections and, finally, the anonymous referees for their valuable comments.

\section{REFERENCES}

Ashton P.M.S., Lowe J.S., and Larson B.C., 1991. Some evidence for the cause of epicormic sprouting in blue mahoe (Hibiscus elatus SW.) in the moist limestone region of Puerto Rico. J. Trop. For. Sci. 3: 123-130.

Auchmoody L., 1972. Epicormic branching: seasonal change, influence of fertilization and frequency of occurence in uncut stands. USDA For. Serv. Res. Paper NE-228: 1-8.

Barthélémy D. and Caraglio Y., 2007. Plant architecture: a dynamic, multilevel and comprehensive approach to plant form, structure and ontogeny. Ann. Bot. 99: 375-407.

Books D.J. and Tubbs C.H., 1970. Relation of light to epicormic sprouting in sugar maple. US For. Ser. Res. Note NC-93, 2 p.

Church T.W. and Godman R.M., 1966. The formation and development of dormant buds in sugar maple. For. Sci. 12: 301-306.

Collett D., 1991. Modelling binary data. Chapman \& Hall, London, 369 p.

Courraud R., 1987. Les gourmands sur les chênes rouvre et pédonculé. Forêt-Entreprise 45: 20-33.

Dhôte J.F., 1997. Effets des éclaircies sur le diamètre dominant dans les futaies régulières de hêtres ou de chênse sessiles. Rev. For. Fr. 49: $557-578$.

Evans J., 1965. The control of epicormics branches. In: Proceedings of a Seminar held at the University of York, 10-12 April 1985, Advances in Practical Arboriculture, Forestry Commission Bulletin 65: 115120.

Evans J., 1982. Silviculture of oak and beech in northern France: observations and current trends. Q. J. For. 76: 75-82.

Fabricius L., 1932. Ursachen der Wasserreiserbildung an Eichen. Forstwissenschaft. Centr.bl. 54: 753-766.

Fink S., 1980. Anatomical studies on the occurrence of shoot and root primordia in the stem region of broadleaved and coniferous trees. 1. Proventitious primordia. Allg. Forst- Jagdztg. 151: 160-180.

Fontaine F., 1999. Les bourgeons épicormiques chez le chêne sessile (Quercus petraea) : établissement des bases en vue de l'évaluation dynamique d'un potentiel épicormique, Thèse de doctorat, Université de Reims Champagne-Ardenne, Volume I, 101 p., Volume II, 94 p.

Fontaine F., Colin F., Jarret P., and Druelle J.-L., 2001. Evolution of the epicormic potential on 17-year-old Quercus petraea trees: first results. Ann. For. Sci. 58: 583-592.

Harmer R., 1990. The Timing of Canopy and Epicormic shoot growth in Quercus robur L. Forestry 63: 279-283.

Harmer R., 1992. Do dominant oaks have few epicormic branches? Forestry Commission Research Division, Research Information Note 223, $4 \mathrm{p}$.

Hedlund A., 1964. Epicormic branching in north Louisiana delta. USDA For. Serv. Res. Note S-O-8: 1-3.

Il'Yyushenko, A.F. and Romanovskij, M.G., 2000. Formation of a secondary crown on pedunculate oak and its role on forest stand dynamics et son rôle dans la dynamique des peuplements forestiers, Lesovedenie 3: 65-72.

Jarret P., 2004. Chênaie atlantique : Guide des sylvicultures. ONF ed., Lavoisier, Paris, $335 \mathrm{p}$.

Joyce P.M., Huss J., McCarthry R., Pfeifer A., and Hendrick E., 1998. Silvicultural guidelines for ash, sycamore, wild cherry, beech and oak in Ireland. COFORD ed., Dublin, 144 p.

Kormanik P.P., Brown C.L., 1969. Origin and development of epicormic branches in sweetgum. USDA For. Serv. Res. Paper SE-54: 1-17. 
Krahl-Urban J., 1955. Forstgenetik in der Eichen- und Buchenwirtschaft. Forstarchiv 26 6: 121-131.

McCullagh P. and Nelder J.A., 1983. Generalised linear models. Monographs on Statistics and Applied Probability. Chapman and Hall, London, 532 p.

Meadows J.S., 1995. Epicormic branches and lumber grade of bottomland oak. In: Proceedings of the 23rd annual hardwood symposium Conference Advances in Hardwood Utilisation: Following Profitability from the Woods through Rough Dimension, Cashiers, NC, Memphis, TN: National Hardwood Lumber Association. Lowery G., Meyer D. (Eds.) 19-25.

Meadows J.S. and Burkhardt E.C., 2001. Epicormic branches affect lumber grade and value in willow oak. South. J. Appl. For. 25: 136-141.

Nicolini E., Chanson B., and Bonne F., 2001. Stem growth and epicormic branch formation in understorey beech trees (Fagus sylvatica L.). Ann. Bot. 87: 1-15.

Nicolini E.Y., Caraglio Y., Pélissier R., Leroy C., and Roggy J.C., 2003. Epicormic branches: a growth indicator for the tropical forest tree Dicorynia guianensis Amshoff (Caesalpiniaceae). Ann. Bot. 92: $97-$ 105 .

Remphrey W. and Davidson C., 1992. Spatiotemporal distribution of epicormic shoots and their architecture in branches of Fraxinus pennsylvanica. Can. J. For. Res. 22: 336-340.

Rey-Lescure E., 1982. Distribution des gourmands sur les fûts de 25 essences en bordures de déboisement. Can. J. For. Res. 12: 687-698.

SAS, 1999. http://v8doc.sas.com/sashtml/

Schalenberg O. and Pierce F.J., 2002. Contemporary statistical models for the Plant and Soil Sciences. CRC Press, Boca Raton, 738 p.
Schmerberg C., 1997. Les arbres face à la lumière. In : La lumière et la forêt, Bulletin Technique ONF $N^{\circ}$ 34, pp. 45-108.

Schmalz J., Frohlich A., and Gebhardt M., 1997. Quality development in young stands of sessile oak (Quercus petraea) in the Spessart district, Hesse: results of a spacing experiment. Forstarchiv 68: 3-10.

Smith H.C., 1966. Epicormic branching on eight species of Appalachian hardwoods, USDA For. Serv. Res. Note NE-53: 1-4.

Spellmann H., 1995. Holzqualität als Beurteilungskriterium im langfristigen Versuchswesen. Forst Holz 23: 743-747.

Spiecker H., 1991. Zur Steuerung des Dickenwachstums und der Astreinigung von Trauben- und Stieleichen (Quercus petraea (Matt.) Liebl. und Quercus robur L.). Schriftenreihe der Landesforstverwaltung, Band 72, $150 \mathrm{p}$.

Stubbs J., 1986. Hardwood epicormic branching. Small knots but large losses. South. J. Appl. For. 10: 214-220.

Ward J., 1992. Response of woody regeneration to thinning mature upland oak stands in Connecticut, USA. For. Ecol. Manage. 49: 219-231.

Wignall T.A. and Browning G., 1988. The effects of stand thinning and artificial shading on epicormic bud emergence in pedunculate oak (Quercus robur L.). Forestry 61: 46-59.

Yokoi S. and Yamaguchi K., 1996. Origin of epicormic branches and effect of thinning on their development in Quercus mongolica var. Grosseserrata. J. Jpn. For. Soc. 78: 169-174.

Zelterman D., 1999. Models for discrete data. Oxford Science Publications, Clarendon Press, Oxford, 233 p. 